\title{
SWOT Analysis of Musales Industry Development in Awat County
}

$$
\text { Tianfei Lan }{ }^{1, a} \text { Xiaoling } \mathrm{Yu}^{1, \mathrm{a}}
$$

${ }^{12}$ Tarim University, the Academic of Economics and Management, Alar, XinJiang, 843300

${ }^{\mathrm{a} e m a i l,}{ }^{\mathrm{b}}$ email,

\author{
Keywords: Musales, SWOT Analysis, Industry Development
}

\begin{abstract}
The Musales industry of Awat County has a unique production of raw materials and unique ethnic and cultural background, nutritious and rich in medicinal value, but there are many disadvantages and limits. With the continuous expansion of production scale of Musales, it also appeared a variety of problems in varying degrees, but also faced with opportunities and threats. In order to further promote the development of Musales industry, this article use SWOT to analyze their strengths, weaknesses, opportunities and challenges and made a plan to our strengths and avoid weaknesses, take advantage of opportunities and overcome the challenges of sustainable development guidelines to provide assistance for the development of Musales industry.
\end{abstract}

\section{Introduction}

Musales of Awat County traditional brewing process of Xinjiang Uygur Autonomous Region Traditional Culture integral part, which began during the Tang Dynasty of ancient Kucha country, after thousands of years of heritage is still used today, Musales it created a unique quality and style, which by virtue of its unique brewing method and mellow taste won the Xinjiang people like, although not rare drinks, but it contains our unique customs and culture of Xinjiang, Awat region is a microcosm of history and culture, but also carries a long wine culture in Xinjiang, Xinjiang important traditional skills Intangible cultural Heritage. In the long history of five thousand years, the wine into almost Chinese society and people's lives in various fields, wine culture in China's traditional culture also occupies a special place. Therefore, Musales industry has great market potential and development. At the same time, in the production process also appeared in varying degrees a variety of problems.

\section{Development Status and Trends of Musales Industry in Awat County}

Introduction of Musales. The main origin of Musales is located in Awat County, the Uyghur people from generation to generation, and the use of a handmade craft brewing fragrant sweet wine. This began brewing process Kucha of ancient Tang Dynasty, has been circulated for thousands of years, is known as a living fossil Western Wine [1]. In 2007, the brewing process was included in the first batch of Xinjiang Uygur autonomous region-level intangible cultural heritage.

Industry Status of Musales in Awat County. Musales main origin located in Awat County, the Philippines is a brewed sweet wine, full of high medicinal value. Its production process is not complicated, during the grape harvest season in Awat County and almost every household will be made of some Uighur families. Uighur compatriots to drinking forthright known, every friend visiting friends when they come up brewed Musales, vine in the underground fire ignited one pairs, dance and sing, wanton drink, some in front of the famous poet Li Bai's poem "cooking for fun and slaughtering sheep, three hundred will have to drink a cup" scene. It also inherited the legacy of the ancient Western wine culture. Today Musales still family workshop production, mainly concentrated in the Xinjiang region Awat, Musales Turpan, Hotan and other regions are also sporadic presence.

"Musales product standard" by the Association of Awat County Musales enacted in 2005 by the quality and technology supervision department. In 2006, Awat County to the State Trademark Bureau for the "Awat Musales" geographical origin certification mark for the protection of national heritage and cultural heritage plays a vital role. 
As of 2015, Awat County Musales production enterprises and handicraft workshop more than 130 scattered households making more numerous, there are more than 30 varieties Musales series, a total of more than 1,500 tons annual output. [2] The products throughout Beijing, Shanghai, Guangzhou and other cities, and even exported to Hong Kong, Macao and other regions.

\section{SWOT Analysis of the Musales Industry}

The development of any industry, there are strengths and weaknesses, opportunities and threats faced, Awat County Musales industry is no exception, but these strengths and weaknesses, opportunities and threats are not static. Under certain conditions even between them can be interchangeable. SWOT analysis of the industry in favor of more information Awat County Musales industry to provide appropriate strategic decisions for the development of Awat County Musales industry and promote the further development of the industry Musales. By Awat County Musales relevant information on industrial development carried out SWOT matrix analysis (Table 1).

Table 1 SWOT matrix analysis

\begin{tabular}{|c|c|c|}
\hline \multirow[b]{2}{*}{$\begin{array}{l}\text { The external } \\
\text { environment }\end{array}$} & Threat（T） & Opportunity（O) \\
\hline & $\begin{array}{l}\text { (1) The abuse of Brand Culture } \\
\text { resources } \\
\text { ( } 2 \text { ) Faces competition from other } \\
\text { wine brand }\end{array}$ & $\begin{array}{l}\text { (1) In line with the main theme of the times } \\
\text { (2) Meet the requirements of the development of } \\
\text { the agricultural economy } \\
\text { (3) The wine industry has great potential }\end{array}$ \\
\hline \multirow[b]{2}{*}{$\begin{array}{l}\text { The Internal } \\
\text { environment }\end{array}$} & Advantage (S) & Disadvantage (W) \\
\hline & $\begin{array}{l}\text { (1) The development is historic } \\
\text { (2) Unique brewing process } \\
\text { (3) Excellent and rich brewing } \\
\text { materials } \\
\text { (4) It has a unique wine culture } \\
\text { (5) It has a high nutritional value }\end{array}$ & $\begin{array}{l}\text { (1) Backward technology, product quality is } \\
\text { uneven } \\
\text { (2) Lack of personnel } \\
\text { (3) Lack of motivation research } \\
\text { (4) The remote location and the local economy } \\
\text { leg behind }\end{array}$ \\
\hline
\end{tabular}

Advantage Analysis (S) of Musales Industry in Awat County. Musales is from Xinjiang Aksu Awat County, the people here have been brewing Musales Royces on for thousands of years. Tang Dynasty poet Wang Han "Liangzhou word" the "magic cup grape wine, to drink Joseph Pipa immediately reminders" in the "wine" refers Musales, Gao Wang Tang tribute to "Western nectar" is the Musales [3]. Due to the local climatic conditions for the cultivation of grapes, so the Uighur compatriots has been brewing heritage ancestors, making Musales in the most primitive way handed down, called the ancient Western culture "living fossil", which for $\mathrm{Mu}$ Rosales brand culture building foundation.

Musales brewing technology with traditional craft and modern wines are very different. Uygur people will crush the grapes after the city after a long boiled to evaporate excess water, and then placed in vats after 40 days of natural fermentation, in order to make the taste is different, but also adding some local specialties according to their preferences, such as : mulberry, medlar, pigeon blood, white apricots. [4] It is because each brew master different preferences, brewing techniques also vary their achievements Musales process and product diversity in ensuring the basic process of natural fermentation and boiling ancestors premise.

Factors affecting wine quality analysis, experts have a word "third by technology, seven by grape", implying that only high-quality wine grapes possible brewing high quality wine. The world's leading wine manufacturers have their own winegrowing estate. Xinjiang Tarim Basin Awat County is located in the northwest, south of the Tianshan Mountains, is a temperate continental climate, drought, sunshine, larger temperature difference is very suitable for grape growing, the "China Musales town" reputation also thanks to this unique climate conditions.

Chinese culture is different from the West, so far, Chinese consumers's knowledge for wine is although improved, but to meet European meal drink wine consumption habits are far. And Musales as Xinjiang native products, where natural conditions guarantee its supply of raw materials, but also for the future development of the industry has laid a good foundation. Therefore, it is easier to be 
broad consumer acceptance.

Disadvantages Analysis (W) Of Musales Industry in Awat County. Awat County in local, homemade Musales almost every family can, but mostly pure hand brewing process is very backward in ensuring the basic process of traditional boiled and natural fermentation same premise, family workshops the production process of creating a Musales diversity, but also resulted in uneven product quality, restricted the development of the industry.

The vast majority of craft brewing technicians are handed down from grandparents, most of them have no concept of the scientific production, it is difficult to produce in line with market high-quality Musales. The higher the level of youth culture are unwilling to learn traditional Musales brewing, the majority of the older generation do not understand Chinese brewer, modern wine-making division of Musales brewing process is confused, so to scientific means brewing Musales producers scarce.

Modern, large-scale, selection of raw materials, as well as to enhance the brand's innovative product quality Musales industry needs to support scientific research, but there is a lack of a specialized agency or department Musales research.

In recent years, "stability overrides everything" is the purpose of work in Xinjiang, so the level of economic development of Xinjiang also lagged behind the mainland provinces and cities is not surprising, but South Xinjiang as the main origin Musales more backward economic level, in addition to remote location inaccessible, severely restricts the development Musales industry.

Industry Opportunities Analysis (O) of Musales in Awat County. September 2014, Premier Li Keqiang at the Summer Davos Forum Publication issued a call "public entrepreneurship and innovation" [5]. A few months later, in turn written into the government work report in 2015, followed by local governments have responded positively, and some also set up a "double hit" The Office. While at the same time as the main producing areas in South Xinjiang cotton, under the impact of the international market, cotton prices have been declining, the income of cotton farmers have had a greater impact, when appropriate planting other crops and grapes, adjusting the industrial after all, the structure of income to help farmers solve the problem of good policy. This proves that the moment is the development Musales industry appreciation.

Judging from the economic and ecological benefits, industrial development Musales both increase the income of farmers, promoting employment but also conducive to environmental protection, planting vines themselves will be able to greening the environment, in line with the sustainable development concept. Meanwhile Musales industry as an important part of efficient characteristic agriculture, the prosperity of the rural economy, promote agricultural restructuring to also play an active role.

Recently, a simple bar graph on wine detonated overseas social networking (as shown in Figure). The figure reflects a major change in the consumption of wine consuming countries, people directly and clearly see the status of the wine industry and wine producers adjust their marketing strategies instructive.

According to the report under the authority of the International Organization of Vine and Wine (OIV), we found a surprising fact and wine consumption is actually the fastest-growing countries China!

Widely planted grape in the world, but $50 \%$ of the vineyards are located in the top five countries. Were Spain, France, Italy, China, Turkey. Asia vineyard area in 2000 rose to $19.4 \%$ of the global share of $24 \%$ in 2013, increased by $127 \%$ the number of Chinese vineyards. On the other hand, the number of vineyards in Europe fell from $62.4 \%$ to $55 \%$. World $15 \%$ of the grapes produced in China. Italy and the United States each accounted for $10 \%$ of the grape yield, $80 \%$ of the world's wine production by the 10 countries.

The above data are sufficient to show that the wine industry has great potential for development. 


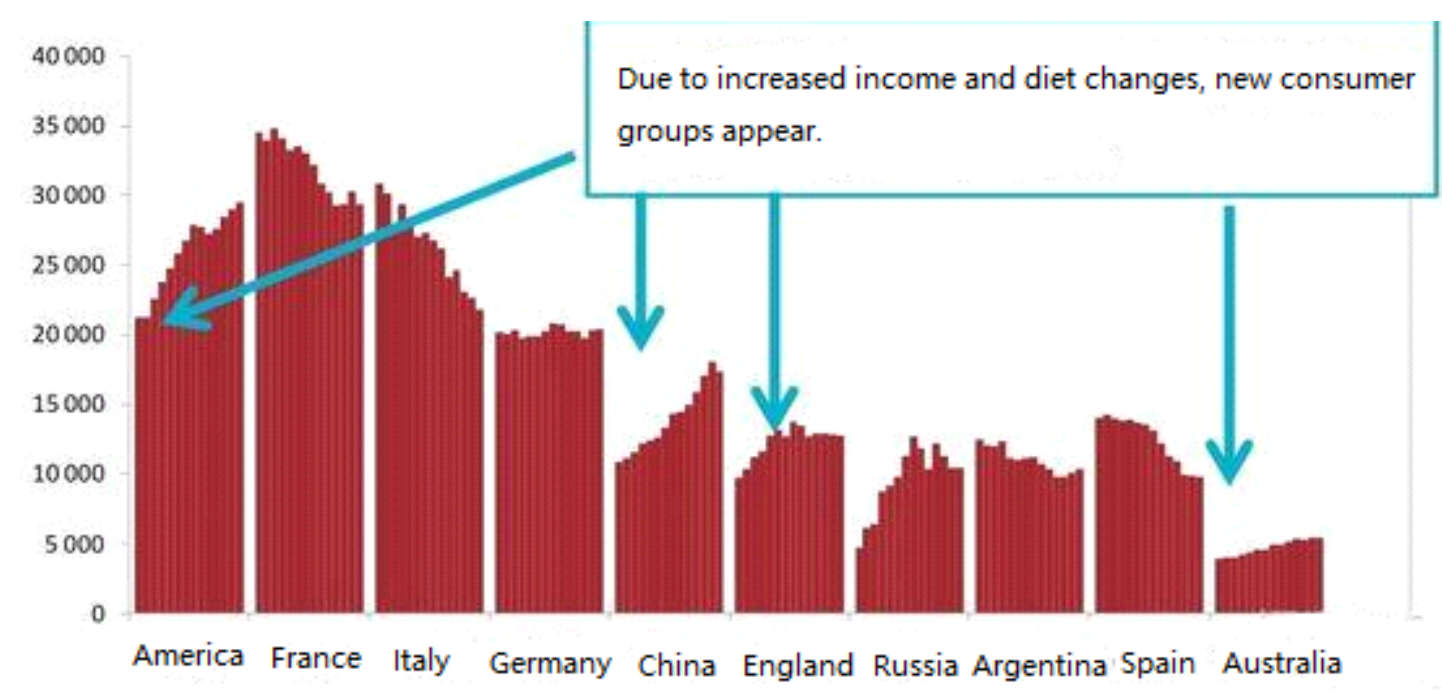

Industry Threat Analysis (T) of Musales in Awat County. Currently, Musales industry outlook is not optimistic. Many companies also use Musales brand resources, and the destruction was almost unrecognizable, affected the normal order of operation of the industry to the development and protection of traditional brewing process industry caused a huge obstacle.

With the improvement of Musales brand awareness and sales continue to rise, some unscrupulous businessmen secretly with the "Musales" brand filling inferior wine into the market, the product quality and low-price products seriously affected the industry's operating order.

Xinjiang scale local enterprises have a dozen wine producers, as well as the Great Wall, Changyu and other brand competition, market share eroded smaller and smaller, and make matters worse, due to the import wine tariff component landing, imports leather on lower prices and the popularity of foreign wines, imported wines will further erode the domestic wine market share. This adds to the pressure of market competition Musales.

\section{Strategic Choice of Musales Industrial Development of Awat County}

Through SWOT analysis of Musales industry in Awat County, we can see that Awat County Musales industry in the development process strengths and weaknesses, the opportunities and challenges. The main problem Awat County Musales industry faces is how to combine the local geographical and cultural characteristics, select the appropriate development strategies hair Yang advantage, overcome weaknesses, seize opportunities and avoid threats.

Government Support Strategy. Awat County Musales industry has a very long history of development, there is an excellent climate and environmental advantages, with the development Musales production quality advantage, begun to take industrial scale, there is room for further development. And to further develop and improve Musales industry without government support.

Grassroots farmers: implement production subsidies, bases, and actively promote the farmers in accordance with pollution, green, organic fruit cultivation and production specifications.

Support cooperatives: cooperatives set up to support farmers, integration of resources sharing. Help cooperation between cooperatives large retailers, and "Farm", saving distribution costs.

Support leading enterprises: support the development of a mature brand and driving ability, good momentum of development of enterprises, to promote large-scale, intensive production. Major support in terms of technical, financial, and promote the optimization and upgrading of industrial structure.

Optimization Brand Strategy. Establish brand awareness, brand strategy, training sales staff, sales team building, set up marketing company, established marketing network, and clear sales channels, expand the sales market. Set up counters at railway stations, airports, shopping malls, etc., to sell sophisticated packaging and printed advertising trademarks and other graphic effects products to expand the influence of the products, create high-quality specialty image.

Industrial Development Strategy. First, set up to foster or several economies of scale and scope 
of the economic advantages of leading enterprises, and even large companies strive to attract multinational investment, thus boosting the Awat County Musales industry consolidation and large-scale development. Or by one of leading enterprises and farmer cooperatives led farmers vineyards scattered to form a co-operative scale, intensive and specialized production pattern. Second, we must make use of the advantages of quality, building export base. Scale production intensification and industrialization is the only way, so to increase financial support, and build social forces, its industrial structure to optimize the integration, the establishment of large-scale production bases.

\section{Acknowledgements}

Fund Project: National Cultural and Technological Support Project - "Tarim Cultural Tourism Integrated Service System and Applications" (2013BAH27F04)

\section{References}

[1] Zhou Lei. Urumqi Evening News, Vol. 7 (2011) No 11, p.25-26

[2] Pan Yunfeng. Xinjiang Geography, Vol. 3 (2014) No 27, p.80-83

[3] Zhu Lixia, Hou Xujie, Xu Qian. Liquor Technology, Vol. 7 (2008) No 19, p.111-135

[4] Yao Ling. Consumer Guide, Vol. 5 (2009) No 27, p.38-39

[5] Song Qinghui. China Daily, Vol. 8 (2015) No 27, p.57-60 